\title{
Metals in Wild and Cultured Dicentrarchus labrax (Linnaeus, 1758) from Fish Markets in Sinop: Consumer's Health Risk Assessment
}

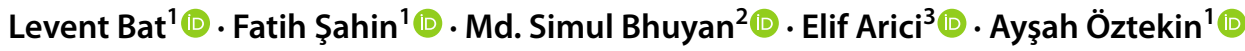

Received: 4 November 2021 / Accepted: 10 December 2021 / Published online: 15 January 2022

(c) The Author(s), under exclusive licence to Springer Science+Business Media, LLC, part of Springer Nature 2021

\begin{abstract}
Concentrations of $\mathrm{Cd}, \mathrm{Hg}, \mathrm{Pb}, \mathrm{As}, \mathrm{Al}, \mathrm{Cu}, \mathrm{Fe}$, and $\mathrm{Zn}$ were determined in the muscles of wild and farmed European seabass in Sinop markets between September and December in 2020, using inductively coupled plasma mass spectrometry after microwave digestion. In the study, iron $(\mathrm{Fe})$, zinc $(\mathrm{Zn})$, aluminum $(\mathrm{Al})$, and copper $(\mathrm{Cu})$ were found higher than the other metals both in wild and cultured Dicentrarchus labrax. These are essential elements, but excess amounts act as a poison. Arsenic (As) concentration was higher than cadmium $(\mathrm{Cd})$, mercury $(\mathrm{Hg})$, and lead $(\mathrm{Pb})$ both in wild and cultured $D$. labrax. The estimated maximum total dietary intakes of these eight metals from both wild and farmed European seabass were below the maximum acceptable daily intake values set by the Turkish Food Codex and European Union Regulation. Results showed that according to metal amounts, consumption of D. labrax had no threat to consumers' health. The target hazard quotient (THQ) revealed that harmful health impacts may not occur. Furthermore, risk index (RI) indicated that there may have a lower risk of developing cancer in the future who have been exposed to $\mathrm{Pb}$ and $\mathrm{As}$ through fish intake. Although the fish are not overly contaminated, the metal level is rising. Increased amounts of heavy metals in fish in different areas could be due to an increase in farm inflow water, domestic sewage, and a number of other anthropogenic sources, all of which should be looked into further. Precautions should be made to safeguard this fish from metal contamination and to reduce the risk to human health.
\end{abstract}

Keywords Heavy metals $\cdot$ Wild and culture $\cdot$ ICP-MS $\cdot$ Dicentrarchus labrax $\cdot$ Consumer health risk

\section{Introduction}

The Black Sea, an inland sea, has unique features in the world. It can be easily affected by all kinds of natural disasters and negativities. It receives contaminants carried by rivers not just from countries bordering the Black Sea, as well as from a wide range of European countries [1]. Contaminants can enter marine ecosystems through a variety of natural and human-caused sources, which include industrial or domestic effluents, pesticide and inorganic fertilizers, rainwater, landfill leaching, shipping and harbor activities,

Levent Bat

leventbat@gmail.com

1 Department of Hydrobiology, Fisheries Faculty, University of Sinop, Sinop, Turkey

2 National Oceanographic and Maritime Institute, Dhaka, Bangladesh

3 Vocational School of Health Services, University of Sinop, Sinop, Turkey atmospheric deposition, and geological erosion of the lithosphere [2-8]. The most important of these contaminants are metals. Metals can be beneficial or toxic to biota and human life depending on their level. Several of these metals are hazardous to live creatures even at trace amounts, while others are physiologically essential but poisonous at high concentrations [9-11]. Metals mix with biomolecules in the body, such as proteins and enzymes, to generate persistent bio-toxic substances, mutilating their properties and inhibiting their bioreactions, when taken in significant amounts. Metals can build up in the edible tissues of fish, which are frequently found at the top of the aquatic food webs [1, 10].

The ever-increasing human population has been increased the demand for food supplies. The demand for fish products has increased due to their high protein content and being cheaper than red meats. The true value of fish in the food system stems not only from its high protein content but also from the two types of omega-3 polyunsaturated fatty acids, namely eicosatetraenoic acid (EPA) and docosahexaenoic acid (DHA). Omega-3 (n-3) fatty acids are necessary for 
proper growth since they reduce cholesterol levels and the risk of cardiovascular disease, stroke, and early birth. Fish also contains vitamins and minerals that are beneficial to the body [12].

Although the amount of fishing in the seas has fluctuated since the $2000 \mathrm{~s}$, it has tended to decrease in recent years. On the other hand, there is an increase in the amount of fish farmed. The fishing production amount of marine fish in Turkey in 2019 was 374,726 tons. On the other hand, the amount of aquaculture production in the seas is 256,930 tons. It is predicted that the amount in aquaculture will exceed the amount in fishing very soon. Turkey has made significant progress in marine aquaculture in the last 10 years. It is thought that the geographical location of Turkey has a great impact on this development in terms of fish production. European seabass is a cultured fish of great importance for the Mediterranean region, having highquality meat in the seas of Turkey. Recently, its cultivation has been increasing in the Black Sea. European seabass is in the top rank among the most cultivated species in Turkey. The production amount of European seabass by aquaculture in 2019 is 137,419 tons [13].

Dicentrarchus labrax L., 1758, which is a solitary and carnivorous species, is fed with crustaceans, small shrimps such as crangonid, small amphipods such as Gammarus in its young period, and fish such as sardines, anchovies, rockfish, as well as crabs and shrimps in its adult period. Fish take up metals from their food and their environment. On the other hand, fish farms use seawater for the cultivation of marine species and use pelleted feed. Farmed fish may absorb dissolved metals from their feeding meals and ambient water, resulting in minor accumulation in various tissues and evoking contamination levels at quality standards.

European seabass, which has very tasty and high-quality meat, is consumed willingly by the public. In Sinop, which is a fishing city, European seabass always finds a place at fishing stalls. The habit of people eating fish in Sinop is higher than in many regions of Turkey.

Because the accumulation of pollutants in fish muscles is widely accepted, the current study is concerned with metal concentrations in fish muscles as they are also the most consumed component by consumers. Additionally, fish store substantial quantities of metals in their tissues, making them a key dietary source of these metals for humans. These ratios may surpass permissible levels in the muscle of such fish in contaminated areas. In this sense, we conduct health risk assessments by detecting the amount of the metals in muscle tissues of both wild and cultured European seabass, as recommended by the Marine Strategy Framework Directive and the values were compared.

The quantities of elements such as cadmium $(\mathrm{Cd})$, mercury $(\mathrm{Hg})$, lead $(\mathrm{Pb})$, arsenic $(\mathrm{As})$, aluminum $(\mathrm{Al})$, copper $(\mathrm{Cu})$, iron $(\mathrm{Fe})$, and zinc $(\mathrm{Zn})$ in the muscle of wild and cultured Dicentrarchus labrax were measured, and their potential risk was calculated using many indicators such as estimated daily intake (EDI), estimated weekly intake (WDI), target hazard quotient (THQ), hazard index (HI), and risk index $(\mathrm{RI})$.

\section{Materials and Method}

The city of Sinop (Turkey) is known as the fishing city. Since there is no industry, fishing comes to the fore. In recent years, the number of fish farmed has approached the amount obtained by fishing. The Ministry has given permission by expanding the aquaculture areas in certain parts of the Sinop coast.

\section{Collection of Fish Samples}

A total of 12 wild and 12 cultured whole fresh European seabass in Sinop (Turkey) markets were purchased between September and December 2020. The fish were cleaned in deionized water, packaged in polyethylene bags, and maintained frozen at $-21^{\circ} \mathrm{C}$ till metal analysis. In this investigation, it was studied in accordance with the Directive on the Protection of Animals Used for Scientific Purposes of the European Parliament and Council [14].

\section{Metal Analysis}

Plastic and glassware were washed and immersed in a $10 \%$ (v/v) $\mathrm{HNO}_{3}$ solution overnight. Then, these were cleansed with deionized water and then dried before use. All of the acids used were from Merck in Germany and were of the best standard.

The fish were thawed and dissected before analysis. Each fish's dorsal side muscle tissues were extracted without skin and homogenized. Bernhard's [15] technique was used to prepare muscle tissues of the fish samples for analysis.

Accredited laboratories employed ICP-MS (Agilent Technologies / 7700X ICP-MS Systems) to assess metals in fish tissues utilizing TURKAK Test TS EN ISO/IEC 17025 and EN 15763 in-house method DMS 19236, which was developed from AOAC (Association of Official Analytical Chemists) 999.10 , to quantify elements using a microwave digestion system (Milestone SK10), and certified reference material (Lobster TORT-2). The accuracy of elements in the certified reference material varied within $10 \%$. The limits of detection (LOD) for $\mathrm{Cd}, \mathrm{Hg}, \mathrm{Pb}, \mathrm{As}, \mathrm{Al}, \mathrm{Cu}, \mathrm{Fe}$, and $\mathrm{Zn}$ were $0.004136,0.002434,0.03223,0.03705,2.114$, $0.07025,0.7099$, and $1.351 \mathrm{ppb}$, respectively. All analyses were performed in triplicate, and the mean values were used to analyze the data. Results are given in $\mathrm{mg} / \mathrm{kg}$ wet weight. 


\section{Calculation of the Daily and Weekly Intakes of Metals}

It is critical to analyze daily metal intake from edible tissues of fish and compare it to the estimated daily intake (EDI) level given by different accredited worldwide organizations for health security under normal consumption habits. This can be obtained simply by multiplying the concentration of each metal in the edible tissues of the European seabass by the average daily quantity of fish consumed per capita.

To evaluate the level of exposure to fish diet, daily and weekly intakes were computed based on the concentration of metals in the edible tissues [16]. The following equation was used to calculate the estimated daily intake (EDI) of metals for consumers in $(\mathrm{mg} / \mathrm{kg} /$ day $)$ :

$\mathrm{EDI}=\frac{\mathrm{C}_{\text {metal }} \times \mathrm{W}_{\text {fish }}}{\mathrm{BW}}$

where $\mathrm{C}_{\text {metal }}$ is the metal amount in European seabass samples $\left(\mathrm{mg} / \mathrm{kg}\right.$, on a wet wt. basis); $\mathrm{W}_{\text {fish }}$ is the daily average fish consumption in this region (g/day); and BW is the consumer's body wt. (kg).

For infants in age group of 1, children age group of 10 , and adults, the study used 13,27 , and $41 \mathrm{~g} /$ day, respectively. Weights are taken as 10,30 , and $70 \mathrm{~kg}$ for infants, children, and adults [17]. Estimated weekly intakes (EWI) were derived from EDI multiplied by 7 as shown in the formula below.

$\mathrm{EWI}=\mathrm{EDI} \times 7$

\section{Consumer's Health Risk Assessment}

The target hazard quotient (THQ) was used to measure the health risks associated with fish consumption by Sinop residents. The following equation describes the method of evaluating risk using THQ as defined in the United States Environmental Protection Agency Region III risk-based concentration table [18-21].

$\mathrm{THQ}=\frac{\text { EDI }}{\text { Rf.D. }} \times 10^{-3}$

The Rf. D. is the oral reference dose of metal (mg/ $\mathrm{kg}$ day), $1.0 \mathrm{E}+00$ for $\mathrm{Al}, 3.0 \mathrm{E}-04$ for $\mathrm{As}, 1.0 \mathrm{E}-03$ for $\mathrm{Cd}, 4.0 \mathrm{E}-02$ for $\mathrm{Cu}, 7.0 \mathrm{E}-01$ for $\mathrm{Fe}, 3.0 \mathrm{E}-04$ for $\mathrm{Hg}$, and 3.0E - 01 for $\mathrm{Zn}$. Reference dose was not given for $\mathrm{Pb}$, but oral slope factor (SFO) value was given as $8.5 \mathrm{E}-03 \mathrm{mg} /$ $\mathrm{kg}$ day. For As, the SFO value is given as well as the RFD value. The SFO value for As is $1.5 \mathrm{E}+00 \mathrm{mg} / \mathrm{kg}$ day $[22,23]$.
The risk index (RI) was calculated using the following formula:

$\mathrm{RI}=\mathrm{EDI} \times \mathrm{SF}$

The RI is considered negligible if the $\mathrm{RI}$ is $<10^{-6}$, allowable or bearable if the $\mathrm{RI}$ is $10^{-6}<\mathrm{RI}<10^{-4}$, and important if the RI is $>10^{-4}$.

The THQs are summed together to generate the hazard index $(\mathrm{HI})$ :

$$
\begin{aligned}
\mathrm{HI}= & \mathrm{THQ}_{\mathrm{Cd}}+\mathrm{THQ}_{\mathrm{Hg}}+\mathrm{THQ}_{\mathrm{As}}+\mathrm{THQ}_{\mathrm{Al}} \\
& +\mathrm{THQ}_{\mathrm{Cu}}+\mathrm{THQ}_{\mathrm{Fe}}+\mathrm{THQ}_{\mathrm{Zn}}
\end{aligned}
$$

If the $\mathrm{HI}$ is less than 1.0 , it is doubtful that there will be evident negative consequences, whereas an $\mathrm{HI}$ more than 1.0 suggests the likelihood of negative consequences. When the HI exceeds ten (10), the risk is considered high, persistent, or even severe $[1,24,25]$.

\section{Statistical Analysis}

The data were analyzed with the SPSS v.21 statistics software. Calculations were made using Microsoft Excel 2019. Statistical differences in the metal levels between wild and cultured European seabass were compared by the Mann-Whitney $U$, or Student's $t$-tests, where appropriate $(p=0.05)$ [26].

\section{Results and Discussion}

$\mathrm{Zn}$ had the highest quantities, whereas $\mathrm{Cd}$ had the lowest (Fig. 1). The mean ( \pm Std Deviation) of $\mathrm{Cd}(0.015 \pm 0.002)$, $\mathrm{Hg}(0.025 \pm 0.007)$, and $\mathrm{Pb}(0.042 \pm 0.005)$ values $(\mathrm{mg} / \mathrm{kg}$ wet wt.) in European seabass was lower than the recommended limits of $\mathrm{Cd}<0.05, \mathrm{Hg}<0.50$, and $\mathrm{Pb}<0.30 \mathrm{mg} /$ $\mathrm{kg}$ wet wt. by European Union Commission Regulation and Turkish Food Codex [27, 28]. Similarly, the As, $\mathrm{Cu}$, and $\mathrm{Zn}$ values averaged $0.11 \pm 0.02,0.25 \pm 0.07$, and $16.87 \pm 4.18 \mathrm{mg} / \mathrm{kg}$ wet wt. in European sea bass, respectively. These results were found to be $9.1,80$, and 3 times less than the recommended $1.0,20$, and $50 \mathrm{mg} / \mathrm{kg}$ wet weight values [29]. In the present study, $\mathrm{Al}$ amounts ranged from 0.11 to $0.19 \mathrm{mg} / \mathrm{kg}$ wet wt. $\mathrm{Al}$ is the third most abundant component in the crust of the earth and has numerous applications in human life. Natural sources, water used in meal preparation, feedstuffs, and tools used in cooking all contribute to the presence of $\mathrm{Al}$ in the availability of food. It is pointed out that $\mathrm{Al}$ levels in foodstuffs can range from 0.1 to $20 \mathrm{mg} / \mathrm{kg}$ [30]. In this study, Fe values were found between 

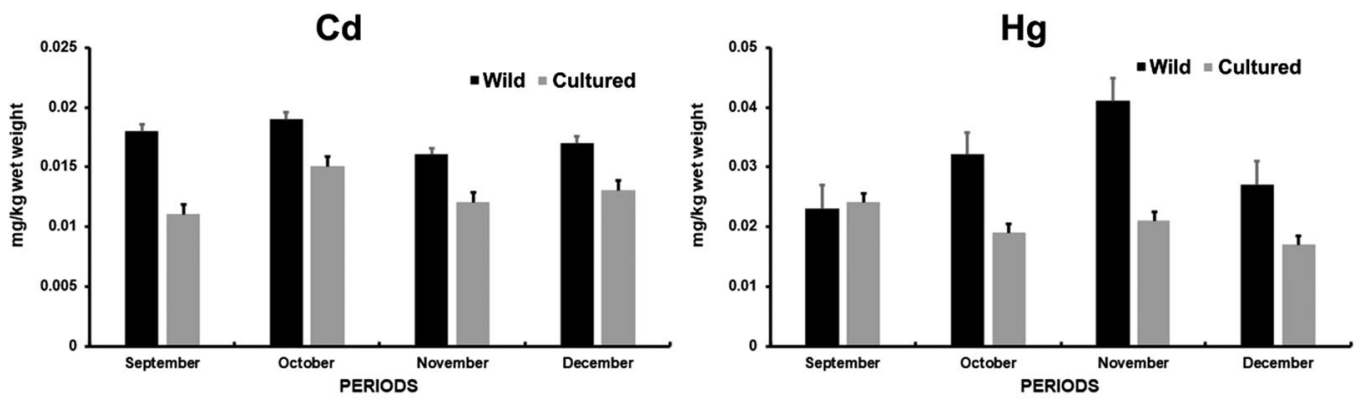

$\mathrm{Pb}$
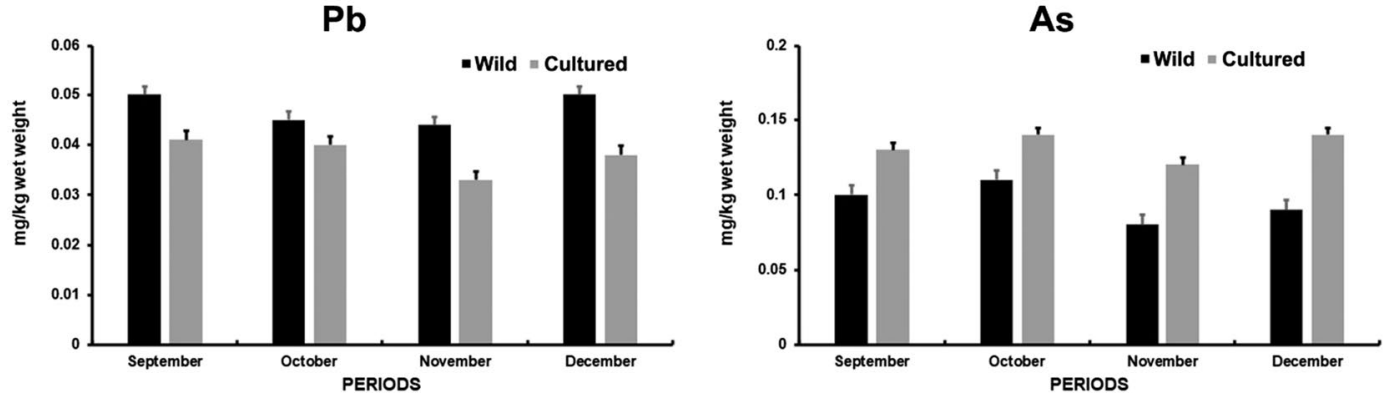

Al

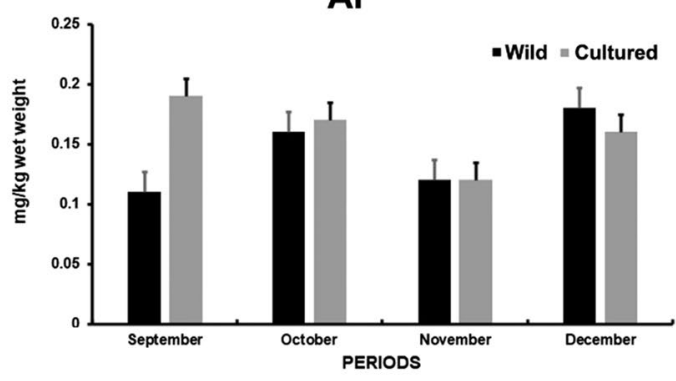

$\mathrm{Cu}$

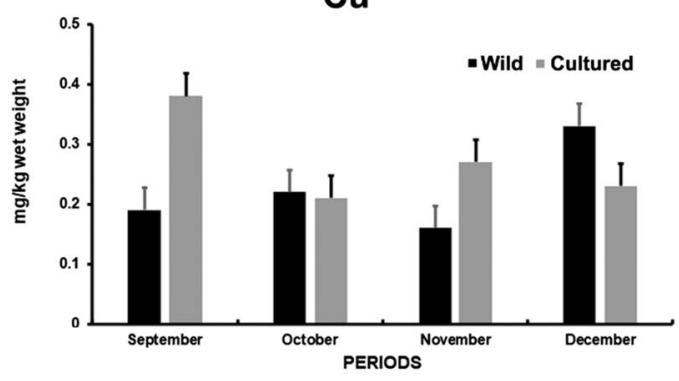

$\mathrm{Fe}$
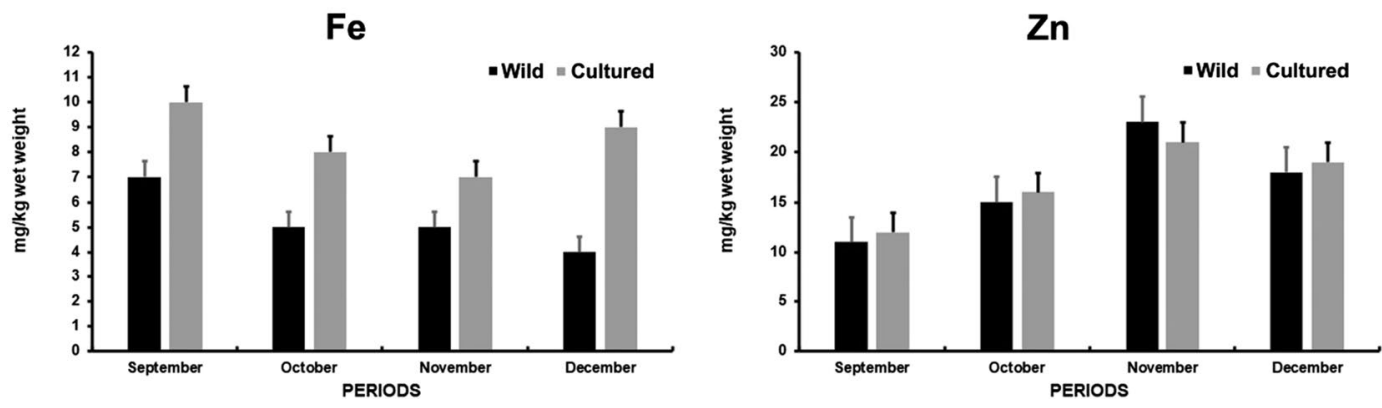

Fig. 1 Toxic and essential elements in muscles of wild and cultured Dicentrarchus labrax (mg/kg wet wt.) from Sinop markets between September and December in 2020

4 and $10 \mathrm{mg} / \mathrm{kg}$ wet wt. Council of Europe [30] pointed out that $\mathrm{Fe}$ is existing in most foods. It has been stated that many foods have $\mathrm{Fe}$ concentrations of up to $150 \mathrm{mg} / \mathrm{kg}$ and the recommended amount of Fe intake is $10-15 \mathrm{mg} /$ day [30]. However, $\mathrm{Cd}, \mathrm{Hg}, \mathrm{Pb}, \mathrm{As}, \mathrm{Al}, \mathrm{Cu}, \mathrm{Fe}$, and $\mathrm{Zn}$ in wild and cultured European seabass from Sinop markets were within the safe limits.

As expected, essential metals were detected higher than toxic metals. Metals such as $\mathrm{Cd}, \mathrm{Hg}, \mathrm{Pb}, \mathrm{As}$, and $\mathrm{Al}$ have no recognized beneficial effects and are well known for their harmful effects on human health, whereas metals like $\mathrm{Cu}, \mathrm{Fe}$, and $\mathrm{Zn}$ are nutritionally vital metals, but their toxic effects on human health begin when they are present at high amounts [31]. These metals can be introduced into the environment by human actions or natural sources. Many studies have been carried out to evaluate the levels of these metals in diverse fish species all over the world [32]. Monthly changes in trace metal content in European seabass can be caused by different environmental and biological factors, such as water physicochemical parameters, physiological and ecological characteristics, and fish habits and diets. 
$\mathrm{Cd}$ and $\mathrm{Pb}$ levels were recorded significantly high in wild European seabass than cultured European seabass, while As and $\mathrm{Fe}$ levels were recorded significantly higher in cultured European seabass compared to wild European seabass $(p<0.05) . \mathrm{Hg}, \mathrm{Al}, \mathrm{Cu}$, and $\mathrm{Zn}$ levels in the wild and cultured European seabass are not found significant differences $(p>0.05)$. Wild European seabass is usually fed with crustaceans and small pelagic fish; however, cultured ones are fed mainly with pellet feeds.

When compared to other studies, the toxic elements $(\mathrm{Cd}, \mathrm{Hg}, \mathrm{As}$, and $\mathrm{Al})$ found in this study were generally low. The highest $\mathrm{Cd}$ value $(3.09 \mathrm{mg} / \mathrm{kg}$ wet wt.) was found in European seabass bought from Trabzon fishing markets [33]. The Hg levels in Table 1 are remarkably similar to those obtained in other investigations. Pb levels were highest in European seabass sampled from Dardanelles [34], followed by those in retailers of Kayseri [35], Paradeniz Lagoon in Mersin [36], and from fish farms in the Aegean Sea [37]. Arsenic is one of the least studied elements and the highest value was obtained from the fish found in Trabzon markets [33], followed by the fish caught in Bafa Lake of Aydın-Muğla [38]. Cu, Fe, and Zn values were determined in wild and farmed fish sampled from the Aegean Sea [37]. The fact that the results of this study are quite low may be stated as the lack of human activities due to the closure and restriction of travel due to COVID-19 in 2020. Continuity of studies is considered very important to arrive at a definitive conclusion.

In Table 1, the level of the metals in D. labrax determined in the present study is compared to those found in other studies.

\section{Health Risk Taxation from Fish Intake}

Based on the metal content in the fish and the amount intake, toxic metals in fish may constitute a health risk to consumers. The term "hazard" refers to the process of identifying the toxicological qualities of a material. Tolerable intake is a term that is commonly used to define safe amounts of consumption; it can be represented in either estimated daily intakes (EDI) or estimated weekly intakes (EWI). In this investigation, the EDIs and EWIs are estimated and shown in Table 2. For babies, children, and adults, intake estimations were reported as $\mathrm{mg} / \mathrm{kg}$ body weight/daily or weekly.

According to the guidelines, the metal consumption from fish muscle tissues was substantially lower and had no negative impacts on the consumers. Because of their toxic effects and accumulation in biota, determining metal amounts in commercial fish species has gotten a lot of attention in many nations in the region and globally. This attention was motivated by a need to ensure the safety supply while limiting the danger to public health.

Table 1 Comparison of measured metal amounts in D. labrax with values taken from the literature as ppm (LOD=limit of detections)

\begin{tabular}{|c|c|c|c|c|c|c|c|c|c|c|}
\hline \multirow[t]{2}{*}{ Sampling area } & \multirow{2}{*}{$\begin{array}{l}\text { Wet/dry } \\
\text { wt }\end{array}$} & \multicolumn{8}{|l|}{ Metals } & \multirow[t]{2}{*}{ References } \\
\hline & & $\overline{\mathrm{Cd}}$ & $\mathrm{Hg}$ & $\mathrm{Pb}$ & As & $\mathrm{Al}$ & $\mathrm{Cu}$ & $\mathrm{Fe}$ & $\mathrm{Zn}$ & \\
\hline Ordu (Perşembe) & Dry & 0.24 & - & $<0.05$ & - & - & 1.01 & 30 & 25.7 & [39] \\
\hline Aegean Sea (Güllük Bay) & Dry & $<0.01-0.04$ & - & $<0.02-0.4$ & - & - & $<0.1$ & & $<0.5-7.2$ & [40] \\
\hline Adana (Çamlık Lagoon) & Dry & 0.08 & - & - & - & - & - & 5.62 & 82.65 & [41] \\
\hline Aegean Sea (from fish farms) & Wet & - & - & - & - & - & - & 24.70 & 2.83 & [42] \\
\hline Aegean Sea (from fish farms) & Wet & - & - & - & - & - & - & 25.77 & 2.89 & [43] \\
\hline Aegean Sea (from fish farms) & Wet & 0.3 & - & 1 & - & - & 3.9 & 51.2 & 45.1 & {$[36]$} \\
\hline Agean Sea (wild) & Wet & 0.20 & - & 0.80 & - & - & 3.00 & 63.10 & 43.60 & {$[36]$} \\
\hline Dardanelles & Dry & 0.19 & 0.03 & 20.00 & - & 37 & 3.00 & 41.00 & $<0.01$ & {$[34]$} \\
\hline İskenderun Bay (from fisherman) & Wet & 0.03 & - & 0.48 & - & - & 1.06 & 33.3 & 10.7 & [44] \\
\hline Mediterranean Sea (İskenderun Bay) & Wet & 0.14 & - & 0.27 & - & - & 1.98 & 0.70 & 2.92 & {$[45]$} \\
\hline Adana (Yelkoma Lagoon) & Wet & 0.10 & - & 0.19 & - & - & 0.71 & 28.90 & 6.01 & [46] \\
\hline Mersin (Paradeniz Lagoon) & Wet & 0.67 & - & 1.02 & - & - & 0.83 & 42.20 & 8.53 & {$[36]$} \\
\hline Sinop (from fish farms) & Dry & 0.00 & $<0.001$ & 0.04 & - & - & $<0.106$ & $<0.38$ & 8.40 & {$[47]$} \\
\hline Aydın-Muğla (Bafa Lake) & Dry & 0.05 & 0.08 & 0.23 & 0.24 & 2.58 & 0.61 & - & - & {$[38]$} \\
\hline Trabzon (from fish markets) & Wet & 3.09 & - & $<$ LOD & 0.29 & - & - & 5.96 & - & {$[33]$} \\
\hline Kayseri (from retailers) & Wet & 0.85 & - & 1.07 & - & - & 1.01 & 12.8 & - & {$[35]$} \\
\hline Sinop (from markets) & Wet & 0.01 & 0.03 & 0.06 & - & - & 0.42 & & 9.20 & {$[48]$} \\
\hline Malatya (from local bazaars) & Wet & - & - & - & - & - & - & 3.12 & 9.41 & [49] \\
\hline Sinop markets wild & Wet & 0.017 & 0.03 & 0.047 & 0.09 & 0.14 & 0.22 & 5.2 & 16.7 & This study \\
\hline Sinop markets cultured & Wet & 0.012 & 0.02 & 0.038 & 0.13 & 0.16 & 0.27 & 8.5 & 17 & This study \\
\hline
\end{tabular}


Table 2 Estimated daily and weekly intake ( $\mathrm{mg} / \mathrm{kg}$ body wt.) of $\mathrm{Cd}, \mathrm{Hg}, \mathrm{Pb}, \mathrm{As}, \mathrm{Al}, \mathrm{Cu}, \mathrm{Fe}$, and $\mathrm{Zn}$ in Dicentrarchus labrax

\begin{tabular}{|c|c|c|c|c|c|c|c|}
\hline \multirow[t]{2}{*}{ Metals } & \multirow[t]{2}{*}{ Fish } & \multicolumn{3}{|l|}{ EDI } & \multicolumn{3}{|l|}{ EWI } \\
\hline & & (Infants) & (Children) & (Adults) & (Infants) & (Children) & (Adults) \\
\hline \multirow[t]{2}{*}{$\mathrm{Cd}$} & Wild & $2.275 \mathrm{E}-05$ & $1.575 \mathrm{E}-05$ & $1.025 \mathrm{E}-05$ & $1.6 \mathrm{E}-04$ & $1.1 \mathrm{E}-04$ & $7.2 \mathrm{E}-05$ \\
\hline & Cultured & $1.657 \mathrm{E}-05$ & $1.147 \mathrm{E}-05$ & $7.467 \mathrm{E}-06$ & $1.2 \mathrm{E}-04$ & $8 E-05$ & $5.2 \mathrm{E}-05$ \\
\hline \multirow[t]{2}{*}{$\mathrm{Hg}$} & Wild & $3.997 \mathrm{E}-05$ & $2.767 \mathrm{E}-05$ & $1.801 \mathrm{E}-05$ & $2.8 \mathrm{E}-04$ & $1.9 \mathrm{E}-04$ & $1.3 \mathrm{E}-04$ \\
\hline & Cultured & $2.632 \mathrm{E}-05$ & $1.822 \mathrm{E}-05$ & $1.186 \mathrm{E}-05$ & $1.8 \mathrm{E}-04$ & $1.3 \mathrm{E}-04$ & $8.3 \mathrm{E}-05$ \\
\hline \multirow[t]{2}{*}{$\mathrm{Pb}$} & Wild & $6.142 \mathrm{E}-05$ & $4.252 \mathrm{E}-05$ & $2.767 \mathrm{E}-05$ & $4.3 \mathrm{E}-04$ & $3 E-04$ & $1.9 \mathrm{E}-04$ \\
\hline & Cultured & $4.94 \mathrm{E}-05$ & $3.42 \mathrm{E}-05$ & $2.225 \mathrm{E}-05$ & $3.5 \mathrm{E}-04$ & $2.4 \mathrm{E}-04$ & $1.6 \mathrm{E}-04$ \\
\hline \multirow[t]{2}{*}{ As } & Wild & $1.235 \mathrm{E}-04$ & $8.55 \mathrm{E}-05$ & $5.564 \mathrm{E}-05$ & $8.6 \mathrm{E}-04$ & $6 E-04$ & $3.9 \mathrm{E}-04$ \\
\hline & Cultured & $1.722 \mathrm{E}-04$ & $1.192 \mathrm{E}-04$ & $7.761 \mathrm{E}-05$ & $1.2 \mathrm{E}-03$ & $8.3 E-04$ & $5.4 \mathrm{E}-04$ \\
\hline \multirow[t]{2}{*}{$\mathrm{Al}$} & Wild & $1.852 \mathrm{E}-04$ & $1.282 \mathrm{E}-04$ & $8.346 \mathrm{E}-05$ & $1.3 \mathrm{E}-03$ & $9 E-04$ & $5.8 \mathrm{E}-04$ \\
\hline & Cultured & $2.08 \mathrm{E}-04$ & $1.44 \mathrm{E}-04$ & $9.371 \mathrm{E}-05$ & $1.4 \mathrm{E}-03$ & $1.01 \mathrm{E}-03$ & $6.6 \mathrm{E}-04$ \\
\hline \multirow[t]{2}{*}{$\mathrm{Cu}$} & Wild & $2.925 \mathrm{E}-04$ & $2.025 \mathrm{E}-04$ & $1.317 \mathrm{E}-04$ & $2.1 \mathrm{E}-03$ & $1.42 \mathrm{E}-03$ & $9.2 \mathrm{E}-04$ \\
\hline & Cultured & $3.079 \mathrm{E}-03$ & $2.452 \mathrm{E}-04$ & $1.596 \mathrm{E}-04$ & $2.2 \mathrm{E}-02$ & $1.72 \mathrm{E}-03$ & $1.1 \mathrm{E}-03$ \\
\hline \multirow[t]{2}{*}{$\mathrm{Fe}$} & Wild & $6.825 \mathrm{E}-03$ & $4.725 \mathrm{E}-03$ & $3.075 \mathrm{E}-03$ & $4.7 \mathrm{E}-02$ & $3.3 E-02$ & $2.1 \mathrm{E}-02$ \\
\hline & Cultured & $1.105 \mathrm{E}-02$ & $7.65 \mathrm{E}-03$ & $4.978 E-03$ & $7.7 \mathrm{E}-02$ & $5.3 \mathrm{E}-02$ & $3.4 \mathrm{E}-02$ \\
\hline \multirow[t]{2}{*}{$\mathrm{Zn}$} & Wild & $2.177 \mathrm{E}-02$ & $1.507 \mathrm{E}-02$ & $9.811 \mathrm{E}-03$ & $1.5 \mathrm{E}-01$ & $1.05 \mathrm{E}-01$ & $6.8 \mathrm{E}-02$ \\
\hline & Cultured & $2.21 \mathrm{E}-02$ & $1.53 \mathrm{E}-02$ & $9.957 \mathrm{E}-03$ & $1.5 \mathrm{E}-01$ & $1.07 \mathrm{E}-01$ & $6.9 \mathrm{E}-02$ \\
\hline
\end{tabular}

According to the directorate General of Fisheries in the Turkish Ministry of Agriculture, the average quantity of fish consumed per person annually in Turkey is $6.7 \mathrm{~kg}$, which is calculated as $18.36 \mathrm{~g}$ per person per day. However, this data does not reflect the truth as it shows the average value obtained by dividing the consumed part of the total fish amount produced and caught that year by the whole population. However, some regions of Turkey do not have the habit of eating fish. Fish consumption is generally higher in coastal cities such as Sinop. In addition, infants, children, and adults consume different amounts of fish. Calculations were made according to the values found in the present study, where infants, children, and

Table 3 Target hazard quotients (THQs) and hazard index (HI) for intake of Cd, $\mathrm{Hg}, \mathrm{As}, \mathrm{Al}, \mathrm{Cu}, \mathrm{Fe}$, and $\mathrm{Zn}$, and the risk index (RI) for intake of $\mathrm{Pb}$ and $\mathrm{As}$ in wild and cultured European seabass from Sinop markets

\begin{tabular}{|c|c|c|c|c|c|c|c|c|c|}
\hline \multirow[t]{2}{*}{ Metal } & \multirow[t]{2}{*}{ Rf. D } & \multirow[t]{2}{*}{ SF } & & \multicolumn{3}{|l|}{ THQ } & \multicolumn{3}{|l|}{ RI } \\
\hline & & & & (Infants) & (Children) & (Adults) & (Infants) & (Children) & (Adults) \\
\hline \multirow[t]{2}{*}{$\mathrm{Cd}$} & $1 E-03$ & & Wild & $2.28 \mathrm{E}-02$ & $1.58 \mathrm{E}-02$ & $1.03 \mathrm{E}-02$ & & & \\
\hline & & & Cultured & $1.66 \mathrm{E}-02$ & $1.15 \mathrm{E}-02$ & $7.47 \mathrm{E}-03$ & & & \\
\hline \multirow[t]{2}{*}{$\mathrm{Hg}$} & $3 E-04$ & & Wild & $1.33 \mathrm{E}-01$ & $9.23 E-02$ & $6.00 \mathrm{E}-02$ & & & \\
\hline & & & Cultured & $8.78 \mathrm{E}-02$ & $6.08 \mathrm{E}-02$ & $3.95 \mathrm{E}-02$ & & & \\
\hline \multirow[t]{2}{*}{$\mathrm{Pb}$} & & $8.5 E-03$ & Wild & & & & $5.22 \mathrm{E}-07$ & $3.61 \mathrm{E}-07$ & $2.35 E-07$ \\
\hline & & & Cultured & & & & $4.20 \mathrm{E}-07$ & $2.91 \mathrm{E}-07$ & $1.89 \mathrm{E}-07$ \\
\hline \multirow[t]{2}{*}{ As } & $3 E-04$ & $1.5 \mathrm{E}+00$ & Wild & $4.12 \mathrm{E}-01$ & $2.85 \mathrm{E}-01$ & $1.85 \mathrm{E}-01$ & $1.85 \mathrm{E}-04$ & $1.28 \mathrm{E}-04$ & $8.35 \mathrm{E}-05$ \\
\hline & & & Cultured & $5.74 \mathrm{E}-01$ & $3.98 \mathrm{E}-01$ & $2.59 \mathrm{E}-01$ & $2.58 \mathrm{E}-04$ & $1.79 \mathrm{E}-04$ & $1.16 \mathrm{E}-04$ \\
\hline \multirow[t]{2}{*}{$\mathrm{Al}$} & $1 \mathrm{E}+00$ & & Wild & $1.85 \mathrm{E}-04$ & $1.28 \mathrm{E}-04$ & $8.35 \mathrm{E}-05$ & & & \\
\hline & & & Cultured & $2.08 \mathrm{E}-04$ & $1.44 \mathrm{E}-04$ & $9.37 \mathrm{E}-05$ & & & \\
\hline \multirow[t]{2}{*}{$\mathrm{Cu}$} & $4 E-02$ & & Wild & $7.31 \mathrm{E}-03$ & $5.06 \mathrm{E}-03$ & $3.29 \mathrm{E}-03$ & & & \\
\hline & & & Cultured & $7.70 \mathrm{E}-02$ & $6.13 \mathrm{E}-03$ & $3.99 \mathrm{E}-03$ & & & \\
\hline \multirow[t]{2}{*}{$\mathrm{Fe}$} & $7 E-01$ & & Wild & $9.75 \mathrm{E}-03$ & $6.75 \mathrm{E}-03$ & $4.39 \mathrm{E}-03$ & & & \\
\hline & & & Cultured & $1.58 \mathrm{E}-02$ & $1.09 \mathrm{E}-02$ & $7.11 \mathrm{E}-03$ & & & \\
\hline \multirow[t]{2}{*}{$\mathrm{Zn}$} & $3 \mathrm{E}-01$ & & Wild & $7.26 \mathrm{E}-02$ & $5.03 \mathrm{E}-02$ & $3.27 \mathrm{E}-02$ & & & \\
\hline & & & Cultured & $7.37 \mathrm{E}-02$ & $5.10 \mathrm{E}-02$ & $3.32 \mathrm{E}-02$ & & & \\
\hline \multirow[t]{2}{*}{$\mathrm{HI}$} & & & Wild & $6.57 \mathrm{E}-01$ & $4.55 \mathrm{E}-01$ & $2.96 \mathrm{E}-01$ & & & \\
\hline & & & Cultured & $8.45 \mathrm{E}-01$ & $5.38 \mathrm{E}-01$ & $3.50 \mathrm{E}-01$ & & & \\
\hline
\end{tabular}


adults consume 5,10 , and $15 \mathrm{~kg}$ of fish annually, which is 13, 27, and $41 \mathrm{~g}$ per day, respectively [17].

Estimating total dietary exposure to inorganic As from food and drinking water using a range of hypotheses, the lower limit on the reference dose for a $0.5 \%$ augmented occurrence of lung cancer $\left(\mathrm{BMDL}_{0.5}=\right.$ benchmark dose lower bound) was measured from epidemiological studies to be $3.0 \mathrm{~g} / \mathrm{kg}$ body wt./day ( $2-7 \mathrm{~g} / \mathrm{kg}$ body wt./day based on the range of assessed total dietary exposure). The Committee determined that the provisional tolerable weekly intake (PTWI) of $15 \mathrm{~g} / \mathrm{kg}$ body wt. (equal to $2.1 \mathrm{~g} / \mathrm{kg}$ body wt./day) was no longer adequate because it was close to the $\mathrm{BMDL}_{0.5}$. The preceding PTWI was withdrawn by the Committee [50].

Food and water are the primary sources of non-occupational human exposure to $\mathrm{Al}$, which is naturally found in variable levels in most meals ingested; hence, food is the main contributor. For all $\mathrm{Al}$ compounds in food, including additives, JECFA issued a PTWI for Al of $1 \mathrm{mg} / \mathrm{kg}$ body wt.; previously established allowable daily intakes and PTWI for its compounds were withdrawn [51].

Assumptions are used in risk assessments. The Risk Assessment Information System (RAIS) describes procedures for calculating the non-cancer risk (THQs) and the goal cancer risk index (RI). The estimated THQs for $\mathrm{Cd}, \mathrm{Hg}$, $\mathrm{As}, \mathrm{Al}, \mathrm{Cu}, \mathrm{Fe}$, and $\mathrm{Zn}$ and $\mathrm{RI}$ for $\mathrm{Pb}$ and As to people due to exposure to these from consumption of wild and cultured European seabass from Sinop markets are calculated and presented in Table 3.

HI, the sum of THQs, was found to be smaller than 1 in both wild and cultured European sea bass. This means that consuming these fish does not pose a threat to humans. The maximum HI was seen in the infants' group, and the lowest was in the category of adults. When it is calculated that $10 \mathrm{~kg}$ infants eat $13 \mathrm{~g}$ fish per day and $70 \mathrm{~kg}$ adults eat $41 \mathrm{~g}$ fish daily [17], it can be said that this proportionally is an expected result. Since $\mathrm{RI}$ for $\mathrm{Pb}$ is $<10^{-6}$, it is considered negligible, and RI for As is $10^{-6}<\mathrm{RI}<10^{-4}$, it is considered permissible or bearable. HI and RI values were calculated slightly less in wild European sea basses than in cultured European seabass.

\section{Conclusion}

According to the findings of this investigation, metal levels in wild and cultivated European seabass species were well below the permitted standards specified by several international institutions. Furthermore, when assessing varied fish-eating habits, the assessment of THQs undertaken in this study revealed that harmful health impacts may not occur. Furthermore, RI who have been exposed to $\mathrm{Pb}$ and
As through fish intake may have a lower risk of developing cancer in the future.

\section{Declarations}

Conflict of Interest The authors declare no competing interests.

\section{References}

1. Bat L, Arici E, Bhuyan MS, Öztekin A, Şahin F (2021) Assessment of toxic and essential elements in muscles of Sparus aurata with special reference to impacts on human health. Research Square (Preprint). 1-15, https://doi.org/10.21203/rs.3.rs-949464/ v1

2. Islam MS, Bhuyan MS, Monwar MM, Akhtar A (2016) Some health hazard metals in commercially important coastal Molluscan species in Bangladesh. Bangladesh J Zool 44(1):123-132

3. Bhuyan S, Islam S (2016) Present status of socio-economic conditions of the fishing community of the Meghna River adjacent to Narsingdi district Bangladesh. J Fish Livest Prod 4:192. https:// doi.org/10.4172/2332-2608.1000192

4. Bhuyan M, Bakar M (2017) Assessment of water quality in Halda River (the Major carp breeding ground) of Bangladesh. Pollution 3(3):429-441

5. Bhuyan MS, Bakar MA (2017) Seasonal variation of heavy metals in water and sediments in the Halda River, Chittagong, Bangladesh. Environ Sci Pollut Res 24(35):27587-27600

6. Bhuyan MS, Islam MS (2017) A critical review of heavy metal pollution and its effects in Bangladesh. Environ Energy Econ 2:12-25

7. Bat L, Öztekin A, Şahin F, Arıcı E, Özsandıkçı U (2018) An overview of the Black Sea pollution in Turkey. Mediterr Fish Aquacult Res 1(2):67-86

8. Alam M, Bhuyan M, Xiangmin X (2021) Protecting the environment from marine pollution in Bangladesh: a brief in legal aspects with response to National and International Cooperation's. Thalassas: An International Journal of Marine Sciences. ALAM, $\mathrm{Md}$, et al. Protecting the Environment from Marine Pollution in Bangladesh: A Brief in Legal Aspects with Response to National and International Cooperation's. Thalassas: An International Journal of Marine Sciences, 37(2): 871-881. https://doi.org/10.1007/ s41208-021-00347-8

9. Bhuyan MS, Islam MS, Akhtar A (2016) Effects of industrialization on fish and fishing community. Scholars' Press, pp. 104

10. Bhuyan MS, Bakar MA, Islam MS, Akhtar A (2016) Heavy metals status in some commercially important fishes of Meghna river adjacent to Narsingdi District, Bangladesh: health risk assessment. Am J Life Sci 4:60-70

11. Bhuyan MS, Bakar MA, Rashed-Un-Nabi M, Senapathi V, Chung SY, Islam MS (2019) Monitoring and assessment of heavy metal contamination in surface water and sediment of the Old Brahmaputra River, Bangladesh. Appl Water Sci 9(5):1-13

12. EFSA NDA Panel (EFSA Panel on Dietetic Products, Nutrition and Allergies) (2014) Scientific Opinion on health benefits of seafood (fish and shellfish) consumption in relation to health risks associated with exposure to methylmercury. EFSA Journal 2014 12(7):3761, 80 pp. https://doi.org/10.2903/j.efsa.2014.3761

13. T.R. the Ministry of Agriculture and Forest General Directorate of Fisheries and Aquaculture (2021) Fishery products statistics. Available at: http://www.tarim.gov.tr/BSGM. Accessed 15 Sep 2021 
14. Union E (2010) Directive 2010/63/EU of the European Parliament and of the Council of 20.10.2010 on the protection of animals used for scientific purposes. Off J Eur Union 276:33

15. Bernhard M (1976) Manual of methods in aquatic environment research. Part 3-Sampling and analyses of biological material (guidelines for the FAO (GFCM)/UNEP Joint Coordinated Project on Pollution in the Mediterranean). Documents Techniques FAO sur les Peches (FAO)

16. USEPA (2000) Risk-based concentration table. Philadelphia PA: United States Environmental Protection Agency, Washington D.C.

17. UNSCEAR (United Nations Scientific Committee on the Effects of Atomic Radiation) (2010) Sources and effects of ionizing radiations, UNSCAR 2008 Report to General Assembly with Scientific Annexes, vol I. United Nations, New York

18. USEPA (1989) Risk assessment guidance for superfund, vol. I: human health evaluation manual (part A). EPA 540/1-89/002. US Environmental Protection Agency, Office of Emergency and Remedial Response. Washington, D.C.

19. Smith RL (1995) EPA region III risk-based concentration table. United States Environmental Protection Agency, 24 pages. Available at: www.chrome-extension://efaidnbmnnnibpcajpcglclef indmkaj/viewer.html?pdfurl=https $\% 3 \mathrm{~A} \% 2 \mathrm{~F} \% 2 \mathrm{Fhwbdocuments.}$ env.nm.gov\%2FLos $\% 2520$ Alamos\%2520National\%2520Labs\% 2FReferences $\% 2 F 9642 . P D F \&$ clen $=1889803 \&$ chunk $=$ true

20. USEPA (2001) Risk assessment guidance for superfund: volume III - part A, process for conducting probabilistic risk assessment EPA 540-R-02-002. US Environmental Protection Agency, Washington D.C.

21. USEPA (2011). USEPA Regional Screening Level (RSL) summary table: November 2011. Available at: http://www.epa.gov/ regshwmd/risk/human/Index.htm . Accessed 15 Sep 2021

22. USEPA (2021) Regional Screening Levels (RSLs) - generic tables: May 2021. Retrieved October 17, 2021, from https://www. epa.gov/risk/regional-screening-levels-rsls-generic-tables.

23. RAIS (2021) The Risk Assessment Information System. University of Tennessee. Retrieved October 17, 2021, from https://rais. ornl.gov/index.html

24. Lei M, Tie B, Song Z, Liao B-H, Lepo JE, Huang Y (2015) Heavy metal pollution and potential health risk assessment of white rice around mine areas in Hunan Province, China. Food Secur 7(1):4554. https://doi.org/10.1007/s12571-014-0414-9

25. Bat L, Arici E, Öztekin A, Şahin F (2021) Farmed Turkish salmon: toxic metals and health threat. Foods Raw Mater 9(2):317-323

26. Zar JH (1996) Biostatistical analysis Prentice-Hall International. Inc, London, pp 1-662

27. Commission Regulation (EC) (2006) Official Journal of the European Union. Setting maximum levels for certain contaminants in food stuffs. Commission Regulation (EC) No 1881/ 2006 364: $5-24$

28. Official Gazette (2011) Turkish food codex contains regulation, Official Gazette Number: 28157 (3rd reiterated) (in Turkish)

29. Official Gazette (1995) Official Gazette of Republic of Turkey. Acceptable levels for chemical and microbiological contaminants in fresh, chilled, frozen and processed fish. (Notification No: 95/6533, Issue: 22223) (in Turkish)

30. Council of Europe (2001) Council of Europe's policy statements concerning materials and articles intended to come into contact with foodstuffs. Policy Statement concerning materials and alloys. Technical Document. Guidelines on metals and alloys used as food contact materials (09.03.2001), Strasbourg, $67 \mathrm{pp}$

31. Goyer R (2004) Issue paper on the human health effects of metals. US Environmental Protection Agency
32. Bat L, Arici E (2018) Heavy metal levels in fish, molluscs, and crustacea from Turkish seas and potential risk of human health. In Food Quality: Balancing Health and Disease, 159-196. Academic Press. https://doi.org/10.1016/B978-0-12-811442-1.00005-5

33. Aydın D, Tokalıoglu Ş (2014) Trace metals in tissues of the six most common fish species in the Black Sea, Turkey. Food Addit Contam Part B 8(1):25-31. https://doi.org/10.1080/19393210. 2014.949873

34. Çoban B, Balkıs N, Aksu A, Güray D, Tekinay A (2009) Heavy metals in livers, gills and muscle of Dicentrarchus labrax (Linnaeus, 1758) fish species grown in the Dardanelles. J Black Sea/ Mediterr Environ 15:61-67

35. Duran A, Tüzen M, Soylak M (2014) Assessment of trace metal concentrations in muscle tissue of certain commercially available fish species from Kayseri, Turkey. Environ Monit Assess 186:4619-4628. https://doi.org/10.1007/s10661-014-3724-7

36. Türkmen M, Türkmen A, Tepe Y (2011) Comparison of metals in tissues of fish from Paradeniz Lagoon in the coastal area of Northern East Mediterranean. Bull Environ Contam Toxicol 87(4):381-385. https://doi.org/10.1007/s00128-011-0381-1

37. Yildiz M (2008) Mineral composition in fillets of sea bass (Dicentrarchus labrax) and sea bream (Sparus aurata): a comparison of cultured and wild fish. J Appl Ichthyol 24(5):589-594

38. Yabanlı M, Coșkun Y, Öz B, Yozukmaz A, Sel F, Öndeș S (2013) Determination of the content of heavy metal in the lake water and sea bass (Dicentrarchus labrax) obtained from Bafa Lake and evaluation in terms of public health. Bornova Veteriner Bilimleri Dergisi 35(49):15-23

39. Topcuoğlu S, Kırbaşoğlu Ç, Güngör N (2002) Heavy metals in organisms and sediments from Turkish Coast of the Black Sea, 1997-1998. Environ Int 27(7):521-526

40. Dalman Ö, Demirak A, Balcı A (2006) Determination of heavy metals $(\mathrm{Cd}, \mathrm{Pb})$ and trace elements $(\mathrm{Cu}, \mathrm{Zn})$ in sediments and fish of the Southeastern Aegean Sea (Turkey) by atomic absorption spectrometry. Food Chem 95:157-162. https://doi.org/10.1016/j. foodchem.2005.02.009

41. Dural M, Göksu MZL, Özak AA, Derici B (2006) Bioaccumulation of some heavy metals in different tissues of Dicentrarchus labrax L, 1758, Sparus aurata L, 1758 and Mugil cephalus L, 1758 from the Çamlık Lagoon of the eastern cost of Mediterranean (Turkey). Environ Monit Assess 118:65-74. https://doi.org/10.1007/s10661-006-0987-7

42. Erkan N, Özden Ö (2007) Proximate composition and mineral contents in aqua cultured sea bass (Dicentrarchus labrax), sea bream (Sparus aurata) analyzed by ICP-MS. Food Chem 102(3):721-725

43. Özden Ö, Erkan N (2008) Comparison of biochemical composition of three aqua cultured fishes (Dicentrarchus labrax, Sparus aurata, Dentex dentex). Int J Food Sci Nutr 59(7-8):545-557. https://doi.org/10.1016/j.foodchem.2006.06.004

44. Türkmen M, Türkmen A, Tepe Y, Töre Y, Ateş A (2009) Determination of metals in fish species from Aegean and Mediterranean seas. Food Chem 113(1):233-237. https://doi.org/10.1016/j.foodc hem.2008.06.071

45. Ersoy B, Çelik M (2010) The essential and toxic elements in tissues of six commercial demersal fish from Eastern Mediterranean Sea. Food Chem Toxicol 48(5):1377-1382. https://doi.org/10. 1016/j.fct.2010.03.004

46. Türkmen A, Türkmen M, Tepe Y, Çekiç M (2010) Metals in tissues of fish from Yelkoma Lagoon, northeastern Mediterranean. 
Environ Monit Assess 168(1):223-230. https://doi.org/10.1007/ s10661-009-1106-3

47. Kocatepe D, Turan H (2012) Chemical composition of cultured sea bass (Dicentrarchus labrax, Linnaeus 1758) muscle. J Food Nutr Res 51(1):33-39

48. Bat L, Öztekin A, Arıcı E (2018) Assessment in terms of human health some heavy metals concentrations determined in Dicentrarchus labrax (Linnaeus, 1758) and Sparus aurata (Linnaeus, 1758) marketed in Sinop (Turkey). Alınteri J Agric Sci 33(1):51-54

49. Ayhan NK, Yaman M (2021) Evaluation of iron and zinc contents of some fish species. Biol Trace Elem Res 1-7. https://doi.org/10. 1007/s12011-021-02745-8

50. Joint F. A. O. WHO Expert Committee on Food Additives, \& World Health Organization. (2011) Safety evaluation of certain contaminants in food: prepared by the Seventy-second meeting of the Joint FAO/WHO Expert Committee on Food Additives (JECFA). World Health Organization

51. World Health Organization (WHO) (2011) Working document for information and use in discussions related to contaminants and toxins in the gsctff. Proceedings of the 5th Session Joint FAO/ WHO Food Standards Programme Codex Committee on Contaminants in Foods. Joint FAO/WHO Food Standards Programme

Publisher's Note Springer Nature remains neutral with regard to jurisdictional claims in published maps and institutional affiliations. 